\title{
A SURVEY OF THE RUBUS SPECIES (ROSACEAE) DESCRIBED FROM THE CANARY ISLANDS
}

\author{
by \\ GÜNTER MATZKE-HAJEK \& HEINRICH E. WEBER*
}

\begin{abstract}
Resumen
MATZKe-HAJeK, G. \& H.E. Weber (1999). Reconocimiento del género Rubus (Rosaceae) en las Islas Canarias. Anales Jard. Bot. Madrid 57(1): 25-35 (en inglés).

Se han estudiado la taxonomía, la nomenclatura y la distribución de las especies de zarzas (Rubus L., subgen. Rubus) descritas de las Islas Canarias. Junto a Rubus ulmifolius Schott, especie muy frecuente en el Mediterráneo, se encontraron dos especies: $R$. bollei Focke (Syn.: $R$. canariensis Focke, $R$. suspiciosus Menezes) y $R$. polmensis A. Hansen. Se incluyen descripciones completas e ilustraciones de algunas características relevantes y que no siempre se han observado en especímenes de herbario revisados. Además, se discuten problemas de tipificación y se describe como nuevo para la ciencia Rubus $\times$ wolfredoi-wildpretii H.E. Weber nothospec. nov., híbrido frecuente entre $R$. bollei y $R$. ulmifolius. $R$. bommuelleri Focke de Gran Canaria debe ser excluido de la lista de las especies canarias, al estar basada su descripción en un specimen dubium.
\end{abstract}

Palabras clave: Macaronesia, distribución, taxonomía, tipificación, zarzas.

\begin{abstract}
Matzke-Hajek, G. \& H.E. Weber. (1999). A survey of the Rubus species (Rosaceae) described from the Canary Islands. Anales Jard. Bot. Madrid 57(1): 25-35.

Taxonomy, nomenclature and distribution of the bramble species (Rubus L., subgen. Rubus) described from the Canary Islands are studied. Apart from the widespread Mediterranean $R$. ulmifolius Schott two species occur: $R$. bollei Focke (Syn.: $R$. canariensis Focke, $R$. suspiciosus Menezes) and R. palmensis A. Hansen. The latter is not an endemic of La Palma as assumed by its discoverer, but is recorded for the first time also in Gran Canaria and Tenerife. Complete descriptions are provided, and illustrations of distinctive features often lacking in herbarium specimens are presented. Problems concerning the typification are discussed. Rubus $\times$ wolfredoi-wildpretii $\mathrm{H}$. E. Weber nothospec. nov., the frequent hybrid between Rubus bollei and R. ulmifolius is described as new to science. Rubus bornmuelleri Focke from Gran Canaria is based on a specimen dubium and has to be deleted from the list of Canarian species.
\end{abstract}

Key words: Macaronesia, bramble, distribution, taxonomy, typification.

\section{INTRODUCTION}

Since Focke in 1887 for the first time focused attention on the "Rubi der Canaren" only a few attempts have been made to elucidate the taxonomy of the Canarian bramble-flora (FOCKE, 1892, 1914; HANSEN, 1972). However, the descriptions, original diagnoses as well as complementary notes, are insufficient for the following reasons: 1) Focke, the author of three names in question (Rubus bollei, R. canariensis,

* University of Vechta, Biology Dept., Driverstr., 22. D-49377 Vechta (Germany). 
$R$. bornmuelleri), had never seen the living plants of the Canarian brambles he described. When he published $R$. bollei for example, he did not even base his findings on any herbarium specimens at all. 2) Many herbarium specimens, including type material, lack characteristic components like stem cuttings, representative leaves from light exposed shoots or typical inflorescences. Collectors were often unable to supply those parts due to the strong ramification or the tall growth of the plants. Others did not know about the requirements for sufficient and instructive herbarium material of Rubus. All this created obscurity and confusion, which were passed on to modern checklists and floras (HANSEN \& SUNDING, 1985; KUNKEL, 1991; HOHENESTER \& WELSS, 1993).

The intention of this contribution is thus:

1) to typify the names Rubus bollei Focke and $R$. canariensis Focke;

2) to examine critically the systematic value and status of the Rubus taxa described from or quoted for the Canary Islands ( $R$. bollei Focke, $R$. bornmuelleri Focke, $R$. canariensis Focke, $R$. palmensis A. Hansen, $R$. suspiciosus Menezes);

3) to complete and rectify insufficient descriptions and to provide illustrations of distinctive characters which are often lacking in herbarium specimens.

The Mediterranean Rubus ulmifolius Schott, common and widespread also in the Canary islands is not discussed here. It has already been treated in detail by MONASTERIO-HUELIN \& WEBER (1996).

\section{MATERIAL}

The study is based on field observations and collections by the authors on the western Canary Islands in 1969 and from 1995 to 1998. Morphological investigations on herbarium specimens have also been carried out on material from B, BM, BREM, C, COI, JE, K, P, TFC and private herbaria. Further institutions have been checked in vain in the search for brambles collected by Bolle.

\section{DESCRIPTIONS}

Rubus bollei Focke, Abh. Naturwiss. Vereine Bremen 9: 405 (1887, “1886”)

Syn.: R. ulmifolius ssp. bollei (Focke) Bornmüller, Bot. Jahrb. Syst. 33: 434 (1903)

Loc. typ. indic.: "In regione laurorum Palmae insulae observavit cl. Dr. E. Bolle..."

Neotypus: La Palma (Canaren). June 1892, R.P. Murray No. 21. (JE!, Fockecollection, selected here)

Syn.: Rubus canariensis Focke, Abh. Naturwiss. Vereine Bremen 9: 405 (1887, "1886")

Loc. typ. indic.: "Crescit in silvis Teneriffae insulae in vicinitate oppidi Orotava." Bourgeau Pl. Canar. no. 755

Lectotypus: Teneriffa - In margine silva vulgaris, E. Bourgeau, die 15. Maii 1845. E. Bourgeau, Plantae Canarienses. No. 755. as "R. fruticosus Linn." (P!, lectotype, selected here)

Syn.: Rubus suspiciosus Menezes, Jom. Sci. Math. Phys. Nat. ser. 2. 7(28): 313 (1910, "1909") pro hybr. $R$. bollei $\times R$. ulmifolius Typus. [Madeira:] Caminho do Arrebentao [em frente da fonte da Telha.] C.A. Menezes 8.1909 (COI!, holotype)

\section{Description}

Stem high-arching up to $3 \mathrm{~m}$ or climbing up to $8 \mathrm{~m}, 10-25 \mathrm{~mm}$ diameter, strongly branched, angled with flat or slightly furrowed sides, dark purple, glabrous or glabrescent with sparse simple hairs, prickles 6-15 per $5 \mathrm{~cm}$, on the angles, subequal, with very broad triangular red base, declining (straight or) slightly curved, 4-8 $\mathrm{mm}$.

Leaves (fig. la-e) digitate, leaflets 5 , becoming leathery, dark green, glabrous and shining above, grey or greyish-white-feltet beneath with contrasting light-brown nerves; terminal leaflet 8-12 $\times 5-9 \mathrm{~cm}$ (in moist, moderately shady sites rich in nutrient even up to $15 \times 12 \mathrm{~cm}$ ), broadly ovate or obovate to nearly round with an acuminate(-cuspidate) apex $8-22 \mathrm{~mm}$ and an entire or emarginate to sometimes cordate base, more or less evenly 


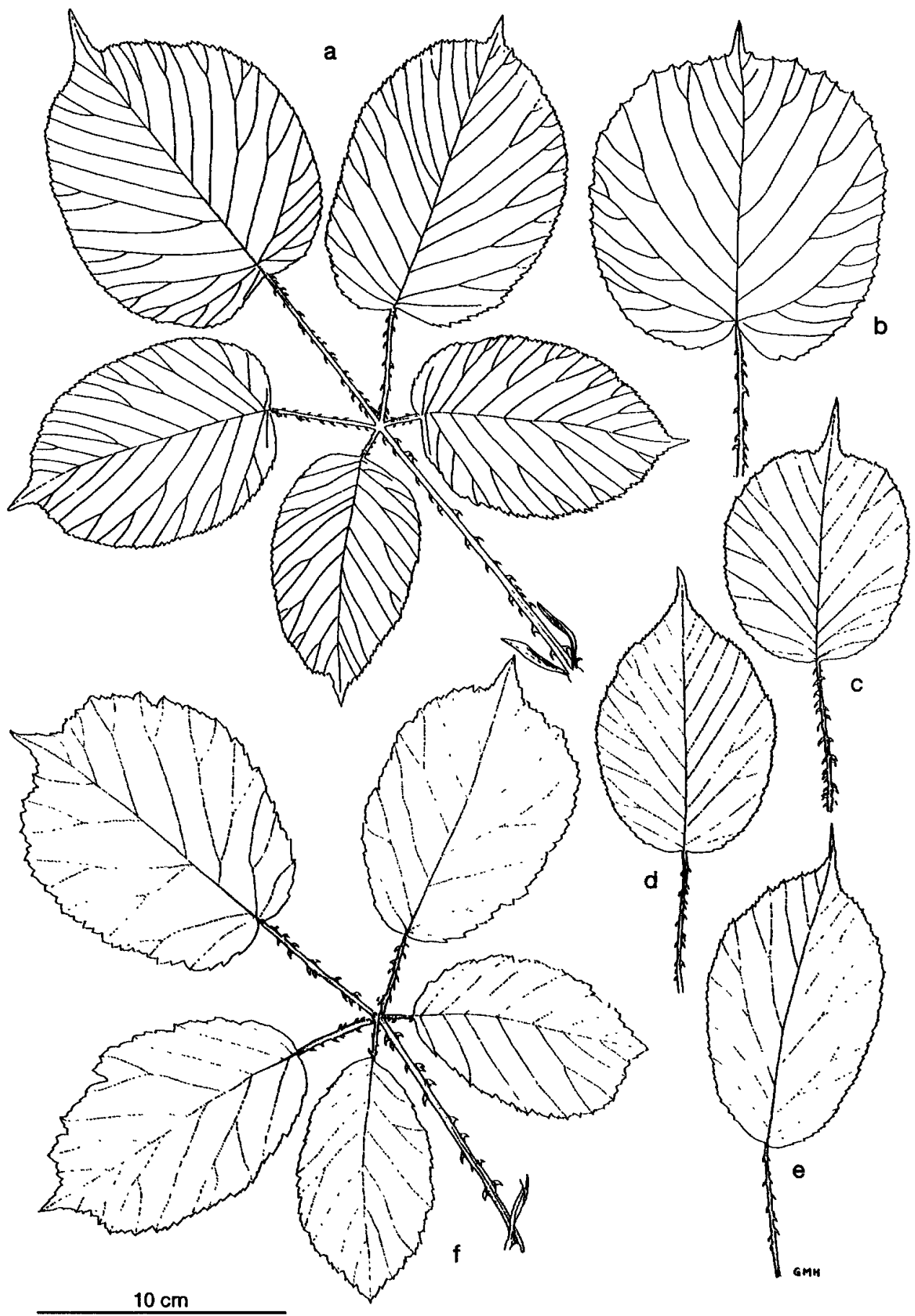

Fig. 1.-Rubus bollei: a, typical leaf; b-e, variability of terminal leaflet. $R . \times$ wolfredoi-wildpretii: $\mathrm{f}$, leaf. 
serrate with teeth-tips straight or introrse and the principle teeth sometimes prominent, slightly convex, the petiolule 35 to $55 \%$ as long as the laminula; petiolules of basal leaflets 4-18 mm; petioles usually as long as or longer than basal leaflets, coloured like the stem with scattered simple and stellate hairs and 8-25 broad-based, often strongly curved prickles 3-5 mm.

Inflorescence large with a wide base of spreading peduncles, with 3-5-foliate leaves below and sometimes 1-2 simple ovate leaves, the cylindrical or conical apex leafless down to about 15 to $30 \mathrm{~cm}$, but with conspicuous bracts up to $3 \mathrm{~cm}$ long; rachis straight with sparse to numerous simple and tufted hairs, grey-feltet above and with sparse to numerous (4-12 per $5 \mathrm{~cm}$ ) broad-based, declining and slightly curved prickles 3-6 $\mathrm{mm}$; pedicels grey-feltet, with few simple patent hairs and a very variable number $(0-15)$ of slender curved prickles c. 1-2 mm; sepals greyish white-feltet, short-pointed, reflexed; petals up to $16 \times 10 \mathrm{~mm}$, broad-ovate, white or rarely pale pink; filaments white, exceeding the green styles; anthers and carpels glabrous; receptacle hairy; flowering in (V)VI(VII). $2 n=14$ (GUSTAFSSON, 1943).

\section{General distribution}

Canary Islands (Gran Canaria, La Gomera, El Hierro, La Palma, Tenerife) and Madeira.

\section{Typification of Rubus bollei}

In the protologue Focke did not mention particular exsiccates, and in his herbarium (JE, BREM) no specimen of $R$. bolle $i$ collected in or before 1887 could be found. Focke even explicitly stated that his fragmentary description was solely based on "observations" submitted by C.A. Bolle. If at all a lectotype can be selected, it must be chosen from the plants Bolle refered to. However, there is no indication that Bolle collected the plant, although Focke called him the "discoverer" of the species. All institutions which according to TL and IH deposit parts of Bolles herbarium (B, FI, K, $\mathrm{MO}, \mathrm{P}-\mathrm{CO}, \mathrm{S}, \mathrm{W})$ were checked in vain.
In any case the current concept of $R$. bollei is hardly founded on the poor and deficient protologue but rather on complementary descriptions and illustrations published by Focke in 1892 and 1914 respectively, after he studied Rubus specimens collected by R.P. Murray on the Canary Islands. Consequently, a neotype is selected from this material, of which six specimens could be traced (JE, B). They are labelled as follows (Murray's handwriting is given here in square brackets).

1) JE: Rubus bollei Focke. Palma (Canaren). Juni 1892 R.P. Murray. [La Palma. June 92. 21.] - Two panicles of $40 \mathrm{~cm}$ length and two leaves with stemcuttings, partitioned on two sheets.

2) JE: Rubus bollei Focke. Teneriffa: roadside near Villa Orotava. July 1892. R.P. Murray. [R. canariensis roadside near Ville Orotava July/92.] - One leafless broad inflorescence with very dense prickles and one leaf with stem cutting. This leaf served as the model for plate 3 in FOCKE (1892) and for the illustration in FOCKE (1914), p. 340. The original drawing still exists in JE.

3) JE: Rubus bollei Focke. Teneriffa: Guimar (Barranco del Ap) Juli 1892 R.P. Murray. [R. canariensis. Guimar. T. (Barranco del Ague). VII/92.24.] Two sheets: two rather small leaves with stem cuttings $6 \mathrm{~mm}$ diameter, and one panicle which is cut into a short, leafy basal part and a $30 \mathrm{~cm}$ apical part.

4) JE, B: Rubus bollei Focke Teneriffa: Metangar. 30 Juni 1892 Rich. P. Murray. [R. canariensis. Matanzas T. 30.VI/92. RPM. 26] - JE: Three sheets: two inflorescences, 40 and $50 \mathrm{~cm}$; the leafy base of inflorescence II has been cut off and mounted on sheet III; two rather small leaves, only one of them with stem cutting. Infl. I was shown in the illustration in FOCKE (1914), p. 339. The duplicate (in B) consisting of two inflorescences. The leaves on this sheet are not stem-leaves, but were cut from the base of the inflorescence. This specimen was given into the B-Herbarium via Bornmüller, who received it from Focke. 
5) JE: Rubus bollei Focke. Teneriffa: Anapa Hills. Juni 1892 R.P. Murray. [R. Bollei. Anaga Hills T. June 192. no barren seen. From same station as those I sent in 1890.] - One inflorescence $45 \mathrm{~cm}$.

All the material cited above is well preserved and belongs to the same taxon. Specimens (3) and (5) are less instructive because they lack fully developed leaves. Parts of specimens (2) and (4) were used by Focke to illustrate the taxon; their remaining parts, however, are rather untypical and both came from Tenerife, an island not quoted in the original description. Therefore specimen (1) has been selected as neotype. It is more complete and its provenance corresponds best to the locality mentioned in the protologue. This designation keeps up the current use of the name Rubus bollei.

\section{Typification of Rubus canariensis}

Analogous to $R$. bolle $i$ the interpretation of $R$. canariensis among taxonomists was dominated by Fockes later publications $(1892,1914)$ rather than by the original diagnosis. Focke's description and illustrations - the latter based also on a specimen collected by R.P. Murray (22. Bco. del Rio near S. Cruz de la Palma, Juni 1892, R. P. Murray) - seem to show specific differences of $R$. canariensis from $R$. bollei: more evenly serrated, narrower terminal leaflets with a less fine apex, and curved prickles on the inflorescence. As a matter of fact, these characters are due to the morphological variability of $R$. bolle $i$ and are not considered here as taxonomically relevant features. This point of view, as a result of actual observations is also in full conformity with the lectotype: Unlike in $R$. bollei, Focke refered to particular herbarium exsiccates in the protologue, namely Bourgeaus Planta Canariensis No 755. The whereabouts of the specimen(s) Focke might have seen, could not be traced. The locality given by Focke is more detailed ("... in vicinitate Oppidi Orotava") than on the lectotype label. Since there is no indication that the syntype is heterogenous, the specimen in Bourgeaus own collection ( $\mathrm{P}$ ) was chosen as lectotype. It is well preserved and consists of a leaf (probably cut from a branch instead of the main barren stem) and a broad, leafy inflorescence. Especially the latter shows the typical features of $R$. bollei, whereas the leaf lacks the stem cutting and is therefore less instructive.

\section{Taxonomy}

Since FOCKE (1914) Rubus bollei has been placed in the series Rhamnifolii (Bab.) Focke of Sectio Rubus and belongs to the few diploid European "primary species" within the genus Rubus L. (GUSTAFSSON, 1943). Unlike apomictic bramble species, $R$. bollei has less constant characters due to normal sexual recombination. There is, for example, a rather broad variability in leaf size and serration (cf. fig. 1a-e), hairyness of leaves and stems, and length of prickles. Just as other diploid bramble species $R$. bolle $i$ may interbreed with other species of Subgenus Rubus and give rise to hybrids. The most widespread hybrid $(R$. bollei $\times$ ulmifolius), according to the frequency of the other parental species (Rubus ulmifolius), is described on page 33 .

In this context it is worth noting that Focke mentioned two characters in the protologue of $R$. bolle $i$ which are rather unusual in this species: "rachis cum pedunculis puberula aculeis rectis parvulis sparsis armata" and "petala... rosea". These deficiencies of the description may result from the fact that Bolle was not experienced in observing Rubus and possibly confused vegetative characters unique to $R$. bolle $i$ with inflorescence-features more typical of the frequent $R$. ulmifolius Schott and hybridogenous plants.

\section{Additional specimens examined}

ESP, GRan Canaria: Tamadaba, $1000 \mathrm{~m}, 16-\mathrm{VII}-$ 1993, M.S. Pascual, TFC 37.122. Bco. del Cernícalo, primavera de 1989, S.O. González \& E.F. Bonafonte, TFC 32.032. LA GOMERA: An der Forstpiste zwi. Meriga und Acevinos, ca. 1,2 km SW La Cerpa, 25-III-1995. Matzke-Hajek, MATZKE-HAJEK. EL HIERRO: Fuente de Tuico, $850 \mathrm{~m}$, Lorbeerwald zwi. Jináma und Frontera, 25-VIII-1994, I. \& P. Schönfelder 94-239, WEBER. LA PaLma: Südl. Tijarafe, wo die Hauptstrasse den Bco. del 
Jurado quert, 16-III-1996, Matzke-Hajek, MATZKEHAJEK. Bco. del Jurado südöstl. Tijarafe, unter der Straße Los Llanos-Puntagorda, 600 m, 28-III-1998, Matzke-Hajek, MATZKE-HAJEK. Ob. Gallegos, nach dem 2. Tunnel von Barlovento, Lorbeerwald. $800 \mathrm{~m}$, UTM Spalte 23/Zeile 89, 2-X-1993, I. \& P. Schönfelder 93-116, WEBER. Ob. Gallegos, nach dem 3. Tunnel, UTM Spalte 24/Zeile 90, 2-X-1993, I. \& P. Schönfelder 93-117, WEBER. Straßenrand nördl. Barlovento, 8-VI1993, Norbert Meyer, MEYER. Monte de los Tilos, pista forestal que lleva al Bco. del Agua, sub R. ulmifolius, 3-I1973, W.W., E.B.T., TFC 16.924. Bco. del Agua, Forstweg 0,5 km östl. Eingang zur Schlucht, 7-VI-1993, Norbert Meyer, MEYER. Bco. del Agua SW Los Sauces, Eingang, Fußweg in die Schlucht, 7-VI-1993, Norbert Meyer, MEYER. Ob. des Bco. del Agua SW Los Sauces, Forstweg bei Espigón Atravesado, 20-III-1996, MatzkeHajek, MATZKE-HAJEK. Bco. del Rio near S. Cruz de la Palma, VI-1892, Murray, JE-FOCKE. Bco. del Juan Major, bei Cubilas, 2,5 km WSW St. Cruz, $370 \mathrm{~m}$ ü NN, 31-III-1998, Matzke-Hajek, MATZKE-HAJEK. Cumbre nueva, Ostseite, $300 \mathrm{~m}$ südl. des Tunnels, 18-III-1996, Matzke-Hajek, MATZKE-HAJEK. Cumbre nueva, Ostseite, Forstweg Los Lomos, 24-III-1996, MatzkeHajek, MATZKE-HAJEK. Cumbre Nueva, Südostseite, neben der Strasse zw. San Isidro und Refugio El Pilar, $3 \mathrm{~km}$ SW S. Isidro, $1000 \mathrm{~m}, 31$-III-1998, Matzke-Hajek, MATZKE-HAJEK. TENERIFE: Cabezo del Tejo, 915-820 m, Lorbeerwald, UTM Spalte 85/Zeile 60, 30-VII-1992, I. \& P. Schönfelder 92-1153, 92-1157, WEBER. Weg zum Cabezo del Tejo, $810 \mathrm{~m}$ Lorbeerwald, UTM Spalte 85/Zeile 59, 30-VII-1992, I. \& P. Schönfelder 92-1146, WEBER. Bco. de los Cochinos, Erjos/El Palmar, 945$1030 \mathrm{~m}$, Lichtung im Lorbeerwald, UTM Spalte 21/Zeile 34, 13-VII-1992, I. \& P. Schönfelder 92-1037, WEBER. Weg im Bco. Ruiz oberhalb der StraRe, 640-700 m, UTM Spalte 41/Zeile 39, 26-VI-1992, I. \& P. Schönfelder 92896, 92-898, 92-899, 92-900, WEBER. Bco. Siete, Lorbeerwaldreste bei El Camino de Chasna, UTM Spalte 50/Zeile 38, 17-VI-1992, I. \& P. Schönfelder 92-835, WEBER. El Pijaral, am Eingang von El Bailadero aus, an offenen Felsen im Lorbeerwald, 16-VIII-1992, $I$. \& P. Schönfelder 92-1198, WEBER. Erjos/El Palmar, Forstpiste, $830 \mathrm{~m}$, Fayal-Brezal, UTM Spalte 22/Zeile 34, 13-VII-1992, I. \& P. Schönfelder 92-1031, WEBER. Erjos/El Palmar, Forstpiste, 900 m, Fayal-Brezal, UTM Spalte 22/Zeile 34, 13-VII-1992, I. \& P. Schönfelder $92-$ 1030, WEBER. Erjos/El Palmar, Lorbeerwald, $1010 \mathrm{~m}$, UTM Spalte 22/Zeile 34, 13-VII-1992, I. \& P. Schönfelder 92-1026, WEBER. Weg zwischen Erjos und El Palmar, Lorbeerwald, ca. $800 \mathrm{~m}$, 29-III-1969, Weber, WEBER. Erjos/Los Tilos, Bco. de las Cuevas negras, 9-VI-1990, I.\& P. Schönfelder 90-129, WEBER. Los Realejos, Parte baja ladera de Tigaiga, 24-VIII-1984, Wolfredo Wildpret de la Torre \& M. del Arca Aquilar, TFC 25.404 indet. Madre del Agua/Agua García, 8-V1980, A. García Gallo, TFC 10453, 10454, indet. Madre del Agua/Agua García, 21-V-1980, A. García Gallo, A. Losada \& A. Viera, TFC 10455, 10456, 10457, indet. Madre del Agua/Agua García, 2-VI-1980, A. García Gallo, L. Negrín \& A. Losada, TFC 10458, 10459 , $10460,10461,10462$, indet. Madre del Agua/Agua
García, 24-IV-1980, W. Wildpret \& A. García Gallo, TFC 10553 indet. Agua Garcia bei Tacoronte: Lorbeerwald am Pfade nach Madre del Agua, ca. $800 \mathrm{~m}$, 24-III-1969, Weber, WEBER. Pista Principal Monte del Agua, Parte Central, UTM 28RCS2035, 30-V-1996, Vicente Lucia Sauquillo, TFC 38.058. Östl. La Estercolada (Anaga), $760 \mathrm{~m}$, Forstpiste im Lorbeerwald, UTM Spalte 73/Zeile 56, 25-VII-1992, I. \& $P$. Schönfelder 92-1125 und 92-1129, WEBER. Vittoria, 30-VI-1892, R.P. Murray, JE-FOCKE. Agua Garcia, 16VIII-1902, M. Vahl, C.

Rubus palmensis A. Hansen, Bot. Not. 125: 379 (1972)

Typus: Canary Islands, La Palma, Cumbre Nueva, on the eastern slope near the tunnel carrying the main road from Santa Cruz to Los Llanos right through the Cumbre, in about $1200 \mathrm{~m}, 1-\mathrm{IX}-1972$, A. Hansen 68 (C!, holotype).

\section{Description}

Stem high-arching, angled, furrowed, 8$20 \mathrm{~mm}$ diameter, with numerous sessile glands (glabrous or) with sparse to numerous, patent, long simple hairs especially on the angles, few to many yellowish-green to redbrown gland-tipped bristles $2-5 \mathrm{~mm}$ and slender acicles and pricklets varying from 1.5 to $6 \mathrm{~mm}$; prickles chiefly on the angles, grading into pricklets or bristles and difficult to count, c. 15-30 per $5 \mathrm{~cm}$, slender or with a broad base, declining and curved, yellow or light brown, 2.5-4(6) $\mathrm{mm}$.

Leaves (figs. 2, 3) digitate, leaflets 5 , glabrescent with short simple adpressed hairs above, thinly hairy beneath; terminal leaflet $14-19 \times 10-15 \mathrm{~cm}$, either ovate with an acuminate apex $2-3.5 \mathrm{~cm}$ and subentire base or roundish with a cuspidate apex $1-2 \mathrm{~cm}$ and cordate base. The roundish leaflets more or less evenly serrate, the ovate ones more shallowly serrate-dentate with the principal teeth slightly prominent and retrorse; leaflets flat or more often convex, the petiolule 40$60 \%$ as long as the lamina; petiolules of basal leaflets 8-30 $\mathrm{mm}$; petiole longer than the basal leaflets, yellow-green, with few to many patent simple hairs, thin gland-tipped bristles $(4 \mathrm{~mm})$ and acicles and 25-40 curved prickles $2-3.5 \mathrm{~mm}$ grading into small acicles. 


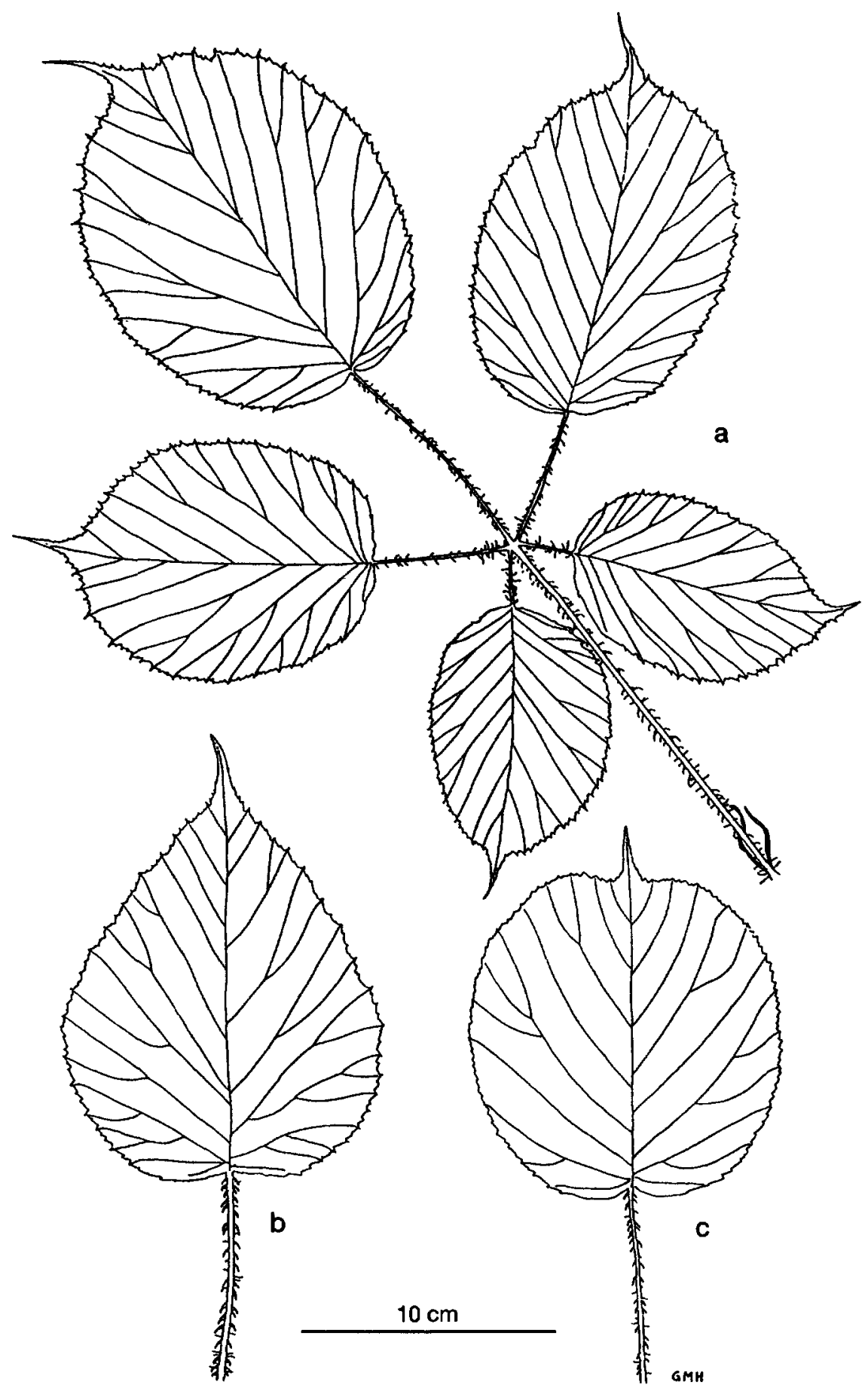

Fig. 2.-Rubus palmensis: a, typical leaf; $b, c$, variability of terminal leaflet. 
Inflorescence extremely broad conicle with wide-spreading peduncles, the upper $30 \mathrm{~cm}$ leafless; rachis straight, grey-feltet above, with few dark-red gland-tipped bristles and per $5 \mathrm{~cm}$ with $8-15$ broad-based, declined, curved prickles, 1-2 mm long. Pedicels 10$30 \mathrm{~mm}$ long with 0-2(5) minute prickles. Sepals, green or greyish-green, narrow with parallel margins, without prickles or bristles, short-pointed, reflexed; petals $12 \times 6 \mathrm{~mm}$ or even longer, narrowly obovate, white; filaments white, exeeding (greenish?) styles. Anthers and carpels glabrous, receptacle slightly hairy. Flowering in VI-VII.

\section{General distribution}

Canary Islands (Gran Canaria, La Palma, Tenerife).

\section{Taxonomy}

The "La-Palma-Blackberry" belongs to the series Grandifolii Focke, a group represented

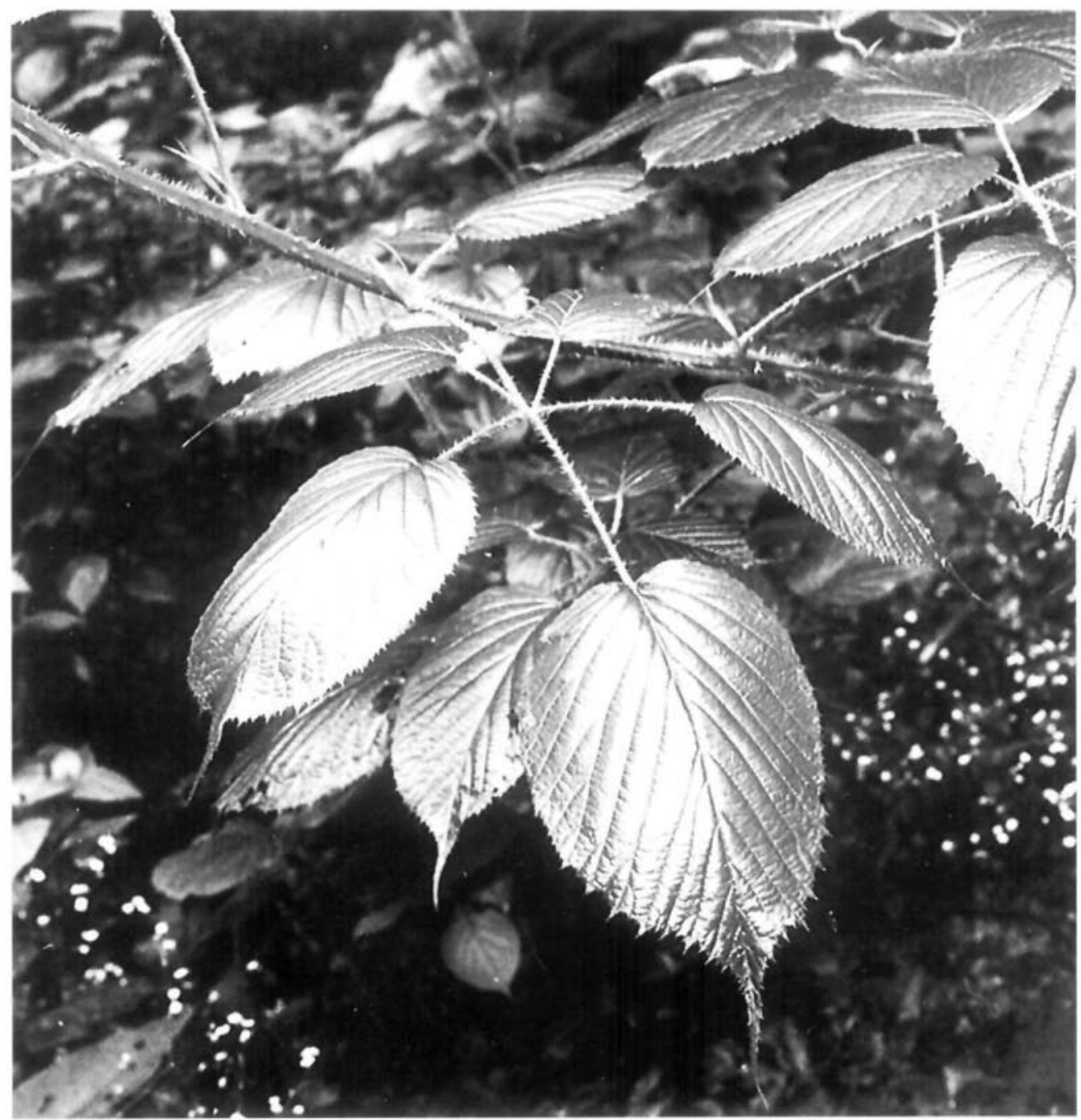

Fig. 3.-Rubus palmensis: Bco. de la Galga, La Palma, 1998, G. Matzke-Hajek. 
by the Madeiran Rubus grandifolius Lowe as the type-species (ICBN, Art. 22.5). Rubus palmensis is a variable taxon, but morphological deviations can be observed within single populations and are obviously the result of environmental influences.

There are plants with leaves greyish-white feltet beneath, particularly at sunny sites, and others with leaflets "supra ut infra viridia concoloria" as described in the protologue and shown on the type material. However the leaves of the holotype specimen are not representative as far as hairyness, colour and size are concerned. Fully developed leaves are extremely large $(40-50 \mathrm{~cm}$ and even more!), have long drip-tips and a fine serration, whereas those of the type material are considerably small (less than $30 \mathrm{~cm}$ ) and show an abnormal coarse serration. Evidently the type specimen was collected from a shady site and cut from side branches or from the apical part of the shoot, as the diameter of the adherent axis clearly indicates. Another inconstant feature is the density of (glandtipped) bristles on stem (1 and 25 per $\mathrm{cm}$ side), petiolules (1-15 pro $\mathrm{cm}$ ) and the inflorescence axis $(0-10$ per $\mathrm{cm})$.

Obviously $R$. palmensis can hybridize with $R$. bollei. Those hybrids seem to be very rare and we could trace only one specimen of really intermediate appearance (La Palma, Forstpiste SW Barlovento, Richtg. Westen, zwischen den ersten beiden Tunnels, 10-VI1993 Norbert Meyer [Herb. MEYER]). Two more herbarium specimens are not complete (La Palma, Bco. de Facundo, 6-VII-1973, E.B. Diez [TFC 33.189]; Gran Canaria, Bco. la Virgen, $850 \mathrm{~m}, 13-\mathrm{VI}-1974$, G. Kunkel $17320[\mathrm{C}]$ ), the fragments, however, show also intermediate characters: Prickles of stems and petiolules like $R$. bolle $i$, leaf serration intermediate, long drip-tips and few gland-tipped bristles like $R$. palmensis. The plant needs further study.

\section{Additional specimens examined}

ESP, Gran Canaria: Bquillo. Grande, Bco. Oscuro, Moya. 975 m, sub R. bollei, 4-1-1980, C. Suárez, TFC 11.077. La Palma: Bco. Franceses, ca. $1000 \mathrm{~m}$, Lorbeerwald, UTM Sp. 21/Zeile 88, 2-X-1993, $I$. \&
P. Schönfelder Nr. 93-113, WEBER. Ob. Gallegos, nach dem 2. Tunnel von Barlovento, $800 \mathrm{~m}$, Lorbeerwald, UTM Spalte 23/Zeile 89, 2-X-1993, I. \& P. Schönfelder 93-115, WEBER. SW Barlovento, Grillplatz an der Waldpiste Richtg. Westen, 10-VI-1993, Norbert Meyer, MEYER. Waldpiste SW Barlovento Richtg. Westen zwischen den beiden ersten Tunnels, 10-VI-1993, Norbert Meyer, MEYER. Ob. des Bco. del Agua SW Los Sauces, Forstweg bei Espigón Atravesado, 20-III-1996, Matzke-Hajek, MATZKE-HAJEK. Bco. de la Galga, 600-500 m, Lorbeerwald, UTM Spalte 28/Zeile 84, 4-X1993, l. \& P. Schönfelder, 93-139, WEBER. Bco. de la Galga, $1.5 \mathrm{~km}$ west of the road from St. Cruz to Los Sauces, 23-III-1998, Matzke-Hajek, MATZKE-HAJEK. Cumbre Nueva, Forstpiste südlich des östlichen Tunnelausgangs, UTM Spalte 24/Zeile 71, 3-X-1993, I. \& P. Schönfelder, 93-125, WEBER. Cumbre Nueva, Ostseite, Forststrasse südl. des Tunnels, 18-III-1996, Matzke-Hajek, MATZKE-HAJEK. Cumbre Nueva, Ostseite, Forststrasse "Los Lomos", 24-III-1996, Matzke-Hajek, MATZKE-HAJEK. Cumbre Nueva, Ostseite, ca. $300 \mathrm{~m}$ östl. des Tunnels an der Straße St. Cruz nach Los Llanos, 15-III-1996, Matzke-Hajek, MATZKE-HAJEK. Lorbeerwald westl. Brena Alta, ca. 850 m, 18-I-1977, Kuhbier, WEBER. Brena Alta, VI1988, Fco. Cabrera Rodríguez, TFC 25766. TENERIFE: Anaga, V-1997, Weber mit Wildpret de la Torre \& al., WEBER. Bailadero, 4-IV-1978, Milbradt, WEBER. Bco. de las Huertas, 4-VII-1973, M. Candelaria Gil Rodriguez, TFC 24.112 indet. El Pijaral, Lorbeerwald, 16-VIII-1992, I. \& P. Schönfelder 92-1197, WEBER. Cabezo del Tejo, Lorbeerwald, 915-820 m, UTM Spalte 85/Zeile 60, 30-VII-1992, I. \& P. Schönfelder 92-1156, WEBER. Cumbres de la Victoria, $1000 \mathrm{~m}, 14-$ VIII-1979, W. Wildpret de la Torre, LN. Sosa, A.G. Gallo, TFC 24.664 sub $R$. bollei).

Rubus $\times$ wolfredoi-wildpretii H.E. Weber, nothosp. nov. $(R$. bollei Focke $\times R$. ulmifolius Schott)

- non R. suspiciosus Menezes, Jorn. Sci. Math. Phys. Nat. ser. 2. 7(28): 313 (1910) ("R. bolle $\times$ ulmifolius") $=R$. bollei Focke (vide p. 26)

Rubus inter Rubum bollei Focke et R. ulmifolium Schott intermedius. Differt a Rubo bollei turione paulo pruinoso, vulgo densius pilis fasciculatis minutis adpressis obsito, aculeis multo gracilioribus, (sub-) rectis; aculeis petiolorum et rachis inflorescentiae distincte gracilioribus, minus curvatis. Inflorescentia vulgo angustiora, petalis semper roseis. Differt a $R$. ulmifolio foliis novissimis \pm rubiginosis (nunquam laete viridibus ut in $R$. ulmifolio), foliis turionis inflorescentiaeque ut in $R$. bollei 
serratis, inflorescentia vulgo $15-25 \mathrm{~cm}$ infra apicem aphylla, formae Rubi bollei similis.

Crescit in Tenerife (fortasse ad Insulis Canariensibus aliis).

Nominatus secundum cl. botanicum amicumque mei Prof. Dr. Wolfredo Wildpret de la Torre, Universidad de La Laguna (Tenerife), eximie meritum in exploratione florae vegetationisque Insularum Canariensium.

Typus: Tenerife, Agua-García near Tacoronte, laurel forest at the path to Madre del Agua, c. $800 \mathrm{~m}$ above sea level, 24-III1969, Weber 69.324.2 (TFC, holotype; Herb. WEBER, isotype).

Rubus intermediary between $R$. bollei and $R$. ulmifolius. Differs from $R$. bollei by the following characters: Stem a little pruinose, usually covered with adpressed numerous to dense small (pseudo-)stellate hairs, its prickles much narrower, straigth or nearly so (not extremely broad-subtriangular with recurved tip), prickles on the petioles (of the stem leaves) and on the rachis of the inflorescence much more slender and less curved. Inflorescence usually narrower, petals always pink. Differs from $R$. ulmifolius as follows: Young leaves more or less rustyred, stem leaves like those of $R$. bollei serrate, inflorescence usually $15-25 \mathrm{~cm}$ beyond the top leafless. Petals paler pink (those of $R$. ulmifolius usually rose-red).

This hybrid lacks particularly the extremely broad, on the stem nearly triangular prickles of $\boldsymbol{R}$. bolle $i$ with their distinctly recurved tips and is moreover easily to be recognized in the field by its \pm rusty-reddish young leaves which remind those of $R$. bollei. It is named on terms of friendship after the well known botanist Prof. Dr. Wolfredo Wildpret de la Torre, University of La Laguna (Tenerife), the leading explorer of the flora and vegetation of the Canary Islands.

The hybrid was demonstrated by the author as a fairly common plant on a joint excursion together with W. Wildpret de la Torre and other colleagues in 1997 in the Anaga Mountains in Tenerife, but not collected at that time. Usually it occurs at sites where both parents grow not very far in the neighbourhood. Besides the type collection, there is only one further typical specimen known: Tenerife, La Laguna, V-1968, T.C. Diaz 633 (TFC, sub R. ulmifolius).

Moreover there is a somewhat doubtful specimen, prickled like $R$. bolle $i$, but with a leaf serration and an inflorescence shape like $R$. ulmifolius: El Hierro, Forstpiste ob. Frontera, $850 \mathrm{~m}$, UTM 03/71, 31-VIII-1994, I. \& P. Schönfelder 92.262 (Herb. SCHÖNFELDER, Herb. WEBER). Possibly it may also be a hybrid of $R$. bollei $\times$ ulmifolius, and in this case in another way intermediary between its parents: Prickles like $R$. bollei, other features like $R$. ulmifolius.

The "hybrid" $R$. bolle $\times$ ulmifolius described and named $R$. $\times$ suspiciosus by Menezes is, according to the holotype, a typical $R$. bollei (see there).

Rubus bornmuelleri Focke, Sp. Rub.: 344 (1914)

= Rubus bornmuelleri Focke ex Bornmüller, Bot. Jahrb. Syst. 33: 435 (1903), publ. inval. (Art. 34.1 ICBN)

Loc. typ. indic.: "Auf Gran Canaria. Gehölz von Doramas in Plantago-Rasen durch Dr. Gidon gesammelt"

Typus: Forêt de Doramas, flore des pelouses a plantain, IV-1901 Gidon; J. Bornmüller, Plantae exsiccatae Canarienses No. 229 (B!, holotype)

The type-specimen is proved to be a holotype, since Bornmüller wrote (in German) on a label "received in San Mateo from a gentleman, who possessed only this single branch". The name was not validly published by Bornmüller (1903), who rather intended an informal communication, stating “... description and publication will not be possible until instructive specimens are procured" (transl.).

The specimen represents a young plant (c. $25 \mathrm{~cm}$ in all) or a shoot derived from a rooted tip. It is probably grown at a shady site. The stem is covered with patent hairs, the small 3-nate leaves have ovate terminal leaflets and are green and hairy on both sides 
(illustration in Focke, 1914, p. 343). The plant lacks all components required for standard material (fully differentiated leaves, inflorescence). A reliable interpretation of its identity is therefore impossible, and it must be regarded as a specimen dubium. However, 3nate, hairy, green leaves and a hairy stem may occur in young plants also of Rubus-species which usually have glabrous leaves and stems, and even Rubus bollei and R. ulmifolius can show these characters unless they are grown under normal light conditions.

\section{ACKNOWLEDGEMENTS}

We would like to thank the curators of the herbaria and all private collectors mentioned for sending us specimens on loan. Special thanks are due to Dr. H. Manitz (JE) for attending the first author during his visit and to Prof. Dr. Wolfredo Wildpret de la Torre, Universidad de La Laguna (Tenerife) who kindly sent us all the Rubus collection at TFC on loan and who guided the second author in 1997 on an excursion to many sites with Rubus in Tenerife. We are also greatly indebted to Ingrid and Prof. Dr. Peter Schönfelder, Universität Regensburg (Germany), for giving us many Rubus specimens they collected in the Canary Islands and which are quoted in this paper. Thanks also to Gaby Beyer, Bonn, for writing the Spanish abstract.

\section{BIBLIOGRAPHIC REFERENCES}

BORNMÜLLER, J. (1903). Ergebnisse zweier botanischer Reisen nach Madeira und den Canarischen Inseln. Bot. Jahrb. Syst. 33: 387-492.

FockE, W.O. (1887, "1886"). Die Rubi der Canaren (Vorläufige Mittheilung). Abh. Naturwiss. Vereine Bremen 9: 405-406.

FocKE, W.O. (1892). Die Rubi der Canaren. Abh. Naturwiss. Vereine Bremen 12: 337-339 + table 3 and 4.

FockE, W.O. (1914). Species Ruborum III. Biblioth. Bot. 83. Stuttgart: E. Schweizerbart.

Gustafsson, A. (1943). The genesis of the European blackberry flora. Acta Univ. Lund. N. F. Ser 2, 39(6). Lund.

HANSEN, A. (1972). A new Rubus species from the Canary Islands. Bot. Not. 125: 379-382.

HANSEN, A. \& P. SUNding (1985). Flora of Macaronesia. Checklist of vascular plants. 3. rev. ed. Sommerfeltia 1: $1-167$

HOHENESTER, A. \& W. WELSS (1993). Exkursionsflora für die Kanarischen Inseln. Stuttgart: Ulmer.

KUNKEL, G. (1991). Flora y vegetación del Archipiélago Canario. Tradado florístico. 2." parte. Dicotiledóneas: $312 \mathrm{pp}$. Las Palmas de Gran Canaria.

KunKel, M.A. \& G. KunKel (1978). Flora de Gran Canaria, vol. II: Enredaderas, trepadoras y rastreras. Edic. Excmo. Cab. Ins., Las Palmas de Gran Canaria.

MeNEZES, C.A. (1910). "Rubus" madeirenses. Jorn. Sci. Math. Phys. Nat.o ser. 2, 7(28): 309-314.

Monasterio-Huelin, E. \& H.E. Weber (1996). Taxonomy and nomenclature of Rubus ulmifolius and Rubus sanctus (Rosaceae). Edinb. J. Bot. 53: 311-322.

Editado por Elena Monasterio-Huelin Aceptado para publicación: 27-V-1999 